Respiration 2010;80:173

DOI: $10.1159 / 000295901$

\section{Endoscopic Lung Volume Reduction in COPD}

Rafal Krenke, Piotr Korczynski, Marta Maskey-Warzechowska

Department of Internal Medicine, Pneumonology and

Allergology, Medical University of Warsaw, Warsaw, Poland

We welcomed with great interest your new series 'New Hope with the Scope' [1]. The selected topics are very attractive and upto-date. It seems to us that the knowledge of the new techniques being developed in pulmonary endoscopy is limited mainly to highly specialized endoscopists and many pulmonologists are not very familiar with the advances in this field. Hence the importance of your initiative.

The first article by Herth et al. [2] presents endoscopic lung volume reduction (ELVR), a novel method in COPD treatment. Although the history of this therapeutic option is relatively short, several different techniques have already been elaborated. The article is a systematic review which describes these techniques in a reader-friendly manner. It was met with enthusiasm by us and our colleagues and triggered a lively discussion which revealed some doubts and points of concern associated with the text. We would like to share them with other readers.

First, the post-ELVR change in quality of life found in the study of Wood et al. [3] was not as high as reported by the authors of the review [ -26.8 points in the St. George's Respiratory Questionnaire (SGRQ)]. Such an increase would have suggested an excellent efficacy of this method of treatment. The highest change reported by Wood et al. [3] was $-8.1 \pm 9.6$ points and was achieved 1 month after ELVR in 30 subjects. Comparable values $(<10$ points) were observed by Springmeyer et al. [4] in a larger series of 98 patients.

Second, we suspect that there is probably an error in the citation positioning of the study by Springmeyer and colleagues [3, 4]. The context of this citation suggests that no pneumothoraces were observed after ELVR in their study. This is true for the study by Wood et al. [3]; however, Springmeyer et al. [4] found pneumothorax the most frequent device-related complication. This is mentioned later by the authors of the review.

The third point concerns the post-ELVR lung functional improvement. The authors present encouraging mean values of postELVR FEV 1 and 6-min walk distance reported by Wan et al. [5]. We found, however, that the differences between mean and median values in this study were substantial (with median values being much lower) [5]. Thus, we suppose the distribution of these values $\left(\mathrm{FEV}_{1}, \mathrm{FVC}, 6\right.$-min walk distance, DLCO) was nonnormal and, if so, median rather than mean values should be quoted.

Finally, we would like to discuss the very interesting perspective of the airway bypass system. Data presented in the review are optimistic, but we believe that they come from the study by Cardoso et al. [6] and not by Lausberg et al. [7], as mentioned in the review [2]. Lausberg et al. investigated human emphysematous lungs in vitro and an observation of 6 months seems to be impossible in this study model.

These few comments do not in any way decrease the value of the review. We would like to emphasize that we consider ELVR a very promising treatment option. We are impatiently awaiting the results of further studies [e.g. the Exhale Airway Stents for Emphysema (EASE) study] and, if they confirm the safety and efficacy of endobronchial devices in treating emphysema, we are looking forward to the possibility of using them in our practice.

\section{References}

1 Herth FJF: New hope with the scope: introduction. Respiration 2010; 79:2-4.

- 2 Herth FJF, Gompelmann D, Ernst A, Eberhardt R: Endoscopic lung volume reduction. Respiration 2010;79:5-13.

-3 Wood D, McKenna R, Yusen R, Sterman D, Ost D, Springmeyer S, Gonzalez H, Mulligan M, Gildea T, Houck W, Machuzak M, Mehta A: A multicenter trial of an intrabronchial valve for treatment of severe emphysema. J Thorac Cardiovasc Surg 2007;133:65-73.

4 Springmeyer S, Bolliger C, Waddell T, Gonzalez X, Wood D: Treatment of heterogeneous emphysema using the spiration IBV valves. Thorac Surg Clin 2009;19:247-253.

5 Wan IYP, Toma TP, Geddes DM, Snell G, Williams T, Venuta F, Yim APC: Bronchoscopic lung volume reduction for end-stage emphysema: report on the first 98 patients. Chest 2006;129:518-526.

-6 Cardoso PFG, Snell GI, Hopkins P, Sybrecht GW, Stamatis G, Ng AW, Eng P: Clinical application of airway bypass with paclitaxel-eluting stents: early results. J Thorac Cardiovasc Surg 2007;134:974-981.

7 Lausberg H, Chino K, Patterson G, Meyers B, Toeniskoetter P, Cooper $\mathrm{J}$ : Bronchial fenestration improves expiratory flow in emphysematous human lungs. Ann Thorac Surg 2003;75:393-397.

Rafal Krenke, MD, PhD

Department of Internal Medicine, Pneumonology and Allergology, Medical University of Warsaw, Banacha 1A PL-02-097 Warsaw (Poland)

Tel. +48 22599 2855, Fax +48 225991560

E-Mail rafalkrenke@interia.pl

\section{KARGER}

Fax +4161306 1234 E-Mail karger@karger.ch www.karger.com (c) 2010 S. Karger AG, Basel

0025-7931/10/0802-0173\$26.00/0

Accessible online at: www.karger.com/res 